\title{
O TRABALHO DE CRIANÇAS E JOVENS NO BRASIL IMPERIAL: MINAS GERAIS, 1831-1832
}

\author{
The children and teens' work in Brazil's \\ Empire: Minas Gerais 1831-1832
}

Tarcísio Rodrigues Botelho*

\begin{abstract}
RESUMO
Apresento evidências sobre a declaração de ocupação de crianças e jovens em listas nominativas de habitantes existentes, para Minas Gerais, na década de 1830. A partir da divisão em três faixas etárias específicas e segundo diversas regiões da província, foi possível verificar que: o perfil das ocupações das crianças e jovens acompanha aquele dos adultos; o padrão do trabalho infantil no que diz respeito ao tipo de ocupação mostrou-se sensível ao perfil econômico das diversas regiões de Minas Gerais; as diferenciações observadas nos padrões de ocupação de crianças e jovens eram determinadas muito mais pelo sexo que pela condição social; não obstante, alguns aspectos permitem diferenciar livres e escravos, unificando-os independentemente do sexo.
\end{abstract}

Palavras-chave: Trabalho infantil, escravidão, Minas Gerais.

\begin{abstract}
I show some evidences about occupation patterns of child and young people in the 1830's Minas Gerais, extracted from nominative lists of inhabitants. I divided the observed group in three age groups and in many regions of the province of Minas Gerais. So, it was possible to see that: the occupational pattern of child and young people follows that of the adults; the patterns of child labor was sensible to the economic patterns of the different regions of Minas Gerais; the observed differentiations in the patterns of child and young occupations was determined much more by sex than by social conditions; and, notwithstanding, some aspects are similar for free and slave people, unifying them by sex.
\end{abstract}

Key-words: Child labor, slavery, Minas Gerais.

* Mestre em Ciências Sociais da PUC-MG e Doutor em História Social pela USP. 


\section{Introdução}

Os estudos sobre crianças e jovens no passado brasileiro têm crescido nos últimos anos. ${ }^{1}$ Entretanto, poucos têm se dedicado ao estudo do trabalho neste segmento da população. Esta dificuldade, a meu ver, reside tanto na escassez de fontes de dados específicos quanto em dificuldades propriamente conceituais. O propósito desta comunicação é apresentar evidências obtidas para o período imperial brasileiro a partir de uma fonte bastante rica que são as listas nominativas de habitantes. Neste caso, trabalharei com as listas existentes para a província de Minas Gerais, resultado da tentativa de organizar um censo provincial na década de 1830. Inicio, porém, com uma discussão sobre o que vem a ser a criança e o jovem nesta sociedade do passado e o significado do trabalho para eles. Em seguida, apresento as fontes a serem utilizadas, apontando suas potencialidades, mas também sua riqueza. Finalmente, exponho os resultados obtidos.

\section{Conceitos}

O trabalho de crianças e adolescentes é alvo de intensos debates na contemporaneidade. Hoje, a proteção da criança e do adolescente "transcende a esfera da vida privada, ganha terreno no plano do que se costumava chamar de 'consciência coletiva' e projeta-se para a ação política na forma de programas, adotados por governos e pela sociedade, em escala doméstica e internacional". ${ }^{2}$ Assim, a proibição do trabalho infantil tornou-se "uma das mais importantes campanhas de conscientização e mobilização de órgãos multilaterais, governos, sindicatos de trabalhadores, empresas e organizações não-governamentais". ${ }^{3}$ Este princípio encontra-se consagrado pela Convenção 138, da Or-

1 Para um balanço dos estudos sobre o tema, ver: GUTIÉRREZ, Horácio; LEWKOWICZ, Ida. Trabalho infantil em Minas Gerais na primeira metade do século XIX. Revista de História. v. 5, n. 2, p. 9-21, 1999.

2 VEIGA, João Paulo Cândia. A questão do trabalho infantil. São Paulo: ABET, 1998, p. 13.

3 Ibid., p. 14. 
ganização Internacional do Trabalho (OIT), adotada em 26 de junho de 1973, que estabeleceu a idade mínima de 14 anos para o trabalho da criança. Tal Convenção, todavia, foi antecedida por outra de 1919 que já estabelecia uma idade mínima para o trabalho na indústria. ${ }^{4}$

De fato, "a preocupação em estabelecer normas tendentes a restringir a utilização do trabalho das crianças, adolescentes e mulheres só se configura com o advento da indústria", tanto nos países pioneiros da industrialização quanto naqueles de industrialização mais tardia, como o Brasil. ${ }^{5}$ Embora crianças sempre tenham trabalhado, este tipo de atividade confundia-se com outros afazeres cotidianos e tendia a ocorrer no espaço doméstico ou próximo a ele. A industrialização, rompendo com os laços entre a vida doméstica e o trabalho, teria aberto espaço para formas bastante intensas de exploração do trabalho infantil. Portanto, pode-se, em princípio, concordar com a afirmação de que a categoria trabalho infantil é invenção do capitalismo, na medida em que transformou o trabalho de crianças em algo extremamente violento e desumano. Segundo Alvim, "rompeu-se com uma tradição de trabalho, em que relações familiares, de vizinhança, eram a garantia de que as crianças, apesar de duramente utilizadas no trabalho em domicílios, tivessem suas capacidades físicas, relacionadas com idade e sexo, respeitadas. Gozavam também de espaços para brincadeiras e não permaneciam longas jornadas trabalhando em serviços inadequados, segundo a tradição, às suas forças". ${ }^{6}$

A discussão acerca deste tipo de trabalho no Brasil tornou-se pública a partir do advento da República, contando com defensores e opositores da proibição do trabalho infantil. O primeiro decreto federal versando sobre a matéria é de 1891 e o Código de Menores é aprovado apenas em 1927. ${ }^{7}$ De todo modo, disseminou-se progressivamente a compreensão quanto à necessidade de se restringir o trabalho infantil. Daí a criação de um "acordo social" contrário ao trabalho dessa faixa etária: "do ponto de vista social mais amplo, do que se considera criança e adolescente, seja a partir da psicologia, da pedagogia, etc., das diversas concepções científicas e do ponto de vista de uma representação social e histórica mais ampla, a infância e a adolescência são períodos de formação; formação esta que passa pela família e pela escola". ${ }^{8}$

4 Ibid., p. 23.

5 PIRES, Júlio Manuel. O trabalho infantil na legislação brasileira. In: ENCONTRO NACIONAL DE ESTUDOS DO TRABALHO 4, Anais... Rio de Janeiro: ABET, 1997, p. 242.

6 ALVIM, Rosilene. Trabalho infantil: diversidade e exploração. In: ENCONTRO NACIONAL DE ESTUDOS DO TRABALHO 4., Anais... Rio de Janeiro: ABET, 1997. p. 299-30.

7 GUTIÉRREZ; LEWKOWICZ, op. cit., p. 10.

8 ALVIM, op. cit., p. 301. 
Ora, se há um "acordo social” acerca do tema, este acordo é construído historicamente. Cabe, portanto, compreender como, nos diversos momentos do passado, percebeu-se o lugar da criança e do adolescente. Indo um pouco além, deve-se perguntar sobre a existência ou não destas categorias (criança e adolescente/jovem) nas sociedades do passado e, daí, questionar acerca do espaço do trabalho na vida destes grupos, ainda que definidos apenas em termos de faixas etárias.

A preocupação com a criança difunde-se no Ocidente a partir do Renascimento e ganha importância progressiva alimentada por dois processos paralelos: o surgimento e progresso da domesticidade e o desenvolvimento da escola. ${ }^{9}$ Estes fenômenos são "dois aspectos do mesmo processo, relacionado com a educação dos jovens para participar em uma sociedade não hierarquizada, profissionalizada, onde o status não era herdado, mas precisava ser alcançado". ${ }^{10}$ Há, pois, um progressivo aumento dos anos reconhecidos como infância e o surgimento de uma nova fase, a adolescência. ${ }^{11}$

Em Portugal, os critérios para definição da infância também eram vagos até o século XIX. Além da ambigüidade das expressões da época, também eram encontradas diferentes delimitações etárias na legislação coeva. ${ }^{12}$ Em fins do século XVIII, os limites para a fase de amamentação das crianças abandonadas nas instituições públicas (os chamados expostos) eram 3 anos ou 1 ano e meio, mas os auxílios se estendiam até os 7 anos. Para aqueles maiores de 7 anos, alertava-se para a necessidade de tutores que velassem por eles até os 20 ou 25 anos. As idades para casamento, por sua vez, estavam fixadas em 12 anos para as mulheres e 14 anos para os homens.

Se em matérias mais abrangentes os critérios eram vagos, quando a questão era o trabalho, a incerteza era ainda maior. As Ordenações Filipinas, que codificavam a legislação civil e parte da criminal no Brasil até princípios do século XX, quase não se referem ao trabalho infantil. Mesmo o que entendemos hoje por criança tinha existência jurídica apenas como menor, como órfão e como enjeitado. ${ }^{13} \mathrm{Na}$ regulamentação da assistência aos enjeitados, as Ordenações Filipinas e legislações anteriores reconheceram a possibilidade de usufruir do trabalho da criança após os 7 anos de idade, pois determinava-se que

9 ARIÉS, Philippe. História social da criança e da família. Rio de Janeiro: Guanabara, 1981.

10 CASEY, James. A história da família. São Paulo: Ática, 1992, p. 175.

11 ARIÉS, op. cit., p. 186-194.

12 VENÂNCIO, Renato Pinto. Famílias abandonadas: assistência à criança de camadas populares no Rio de Janeiro e em Salvador, séculos XVIII e XIX. Campinas: Papirus, 1999, p. 18-23.

13 GUTIÉRREZ; LEWKOWICZ, op. cit., p. 11; VENÂNCIO, op. cit., p. 22-23, 142. As referências a crianças nas Ordenações Filipinas aparecem no Livro I, Títulos 88 e 89. 
se o Juiz considerasse que quaisquer pessoas haviam criado algum órfão até essa idade sem nada receber "deixarão ter de graça outros tantos anos, quantos os assim criaram sem preço". ${ }^{14}$ Ou seja, poderiam dispor do trabalho da criança de que haviam cuidado até que esta completasse 14 anos. Ainda sobre o destino das crianças enjeitadas, a partir de fins do século XVIII e ao longo do século XIX, foram criadas formas de absorção destes órfãos em instituições onde pudessem aprender diferentes ofícios, como as chamadas "casas pias" e os Arsenais da Marinha. Nestes casos, a idade de entrada também era aos 7 anos..$^{15}$

A legislação brasileira que melhor explicita as idades consideradas como limites para o trabalho do que hoje chamamos de criança e de adolescente é a Lei do Ventre Livre, de 28 de setembro de 1871. Por ela, tornavam-se livres todos os filhos de escravas nascidos após a sua publicação. Entretanto, estas crianças permaneceriam com suas mães até os 7 anos de idade. A partir daí e até os 14 anos, os senhores poderiam usufruir dos serviços destas crianças como forma de minimizar os custos de sua criação. Dos 14 aos 21 anos de idade, os jovens seriam entregues ao governo, mediante indenização aos senhores, das suas mães por sua criação, ou trabalhariam para estes senhores a fim de ressarcirem os custos com sua criação neste período. ${ }^{16}$

Tais considerações permitem, portanto, estabelecer algumas faixas etárias como relevantes para compreender o trabalho de crianças e jovens no passado brasileiro. Até os sete anos, a criança não se envolvia formalmente com o trabalho, embora a indivisibilidade entre mundo doméstico e mundo do trabalho fizesse com que ela fosse continuamente solicitada a prestar pequenos serviços. A partir dos 7 anos, todavia, mudava-se de status. Já se podia exigir do pequeno trabalhador um maior envolvimento com atividades sistemáticas no mundo do trabalho, as quais inclusive faziam parte do seu processo de formação profissional. Com 14 anos, admitia-se que o jovem era um trabalhador completo. Poderia eventualmente continuar seu processo de aprendizagem em um ofício mais sofisticado, mas as exigências a ele feitas passavam a ser equivalentes às de um adulto. Obviamente, para os filhos da elite a escola era o caminho natural e a ocupação privilegiada ao longo de todo este período de vida.

14 Ibid., título 88, par. 11.

15 VENÂNCIO, op. cit., p .149-151.

16 Para análises mais detidas da Lei do Ventre Livre, ver: GEBARA, Ademir. $O$ mercado de trabalho livre no Brasil. São Paulo: Brasiliense, 1986; e LAMOUNIER, Maria Lúcia. Da escravidão ao trabalho livre: a lei de locação de serviços de 1879. Campinas: Papirus, 1988. 
Para o presente estudo, vou utilizar esta divisão etária na apresentação de minhas evidências, mesmo que elas contrariem as faixas etárias qüinqüenais, normalmente utilizadas por demógrafos e economistas. Assim, apresento um primeiro grupo etário de 0 a 6 anos, outro de 7 a 13 anos e o último de 14 a 21 anos.

\section{Fontes}

Conforme assinalei na abertura deste texto, as informações sobre trabalho infantil no passado brasileiro são raras e esparsas. Uma das fontes principais são aquelas de caráter censitário, utilizadas especialmente nos estudos de história demográfica, que no caso brasileiro revestem-se de caráter especial. A questão das fontes é tão crucial para o historiador demógrafo que se costuma dividir a história demográfica em períodos distintos, conforme o tipo de documentação disponível. Para o Brasil, Maria Luíza Marcílio apresenta três períodos sucessivos. O primeiro, chamado de pré-estatístico, inicia-se com a colonização e se estende até meados do século XVIII. Caracteriza-se pela existência de poucas fontes propriamente demográficas, com algumas estimativas globais da população brasileira, em bases frágeis. O chamado período proto-estatístico iria de meados do século XVIII até a realização do Recenseamento Geral do Império do Brasil, em 1872. Neste momento, os dados de base se tornam mais abundantes e permitem estudos isolados, sobretudo em função da relativa abundância de listas nominativas de habitantes para algumas regiões. A fase estatística, por sua vez, inaugurada com o Recenseamento de 1872, é aquela em que se pode contar com estatísticas globais confiáveis, frutos dos recenseamentos decenais. ${ }^{17}$

Outros autores, todavia, dividem a demografia histórica brasileira em apenas duas fases: a pré-censitária e a censitária. A primeira vai do início da colonização até o Recenseamento de 1872. Nela, os dados são esparsos e os totais de população para o Brasil são predominantemente estimativas. A fase seguinte é aquela em que se passa a contar com os censos nacionais (1872 em diante). ${ }^{18}$ Seguindo estas classificações, este estudo será predominantemente proto-estatístico ou pré-censitário. Como fontes principais de dados estatísti-

17 MARCÍLIO, Maria Luiza. A população do Brasil em perspectiva histórica. In: COSTA, Iraci Del Nero da. (Org.). Brasil: história econômica e demográfica. São Paulo: IPE/USP, 1986, p. 14.

18 PAIVA, Clotilde Andrade; CARVALHO, José Alberto Magno de; LEITE, Valéria da M. Demografia. In: Instituto Brasileiro de Geografia e Estatística - IBGE. Estatísticas históricas do Brasil: séries econômicas, demográficas e sociais de 1550 a 1988. Rio de Janeiro: IBGE, 1990, p. 22-24. 
cos, tomarei as listas nominativas de habitantes existentes para Minas Gerais na década de 1830 .

As listas nominativas de habitantes são uma das principais fontes de dados demográficos para o chamado período proto-estatístico ou pré-censitário. Nelas são arrolados nominalmente todos os habitantes de uma dada circunscrição administrativa (distrito, paróquia etc.). As informações contidas nestes documentos são variáveis, mas em geral eles permitem levantar, dentre outros, dados quanto ao sexo, idade, profissão e distribuição por domicílio da população em foco. A riqueza e quantidade deste material produzido para alguns países permitiram o desenvolvimento de técnicas especiais de análise demográfica. A mais difundida é aquela criada na Inglaterra pelo Cambridge Group for the History of Population and Social Structure, baseada na análise da composição dos domicílios. ${ }^{19}$ Mas o próprio Louis Henry, criador da técnica de reconstituição de famílias, que revolucionou o estudo das populações do passado, adaptou seu trabalho para permitir o uso das abundantes listas nominativas disponíveis para a capitania e província de São Paulo de meados do século XVIII a meados do século XIX. ${ }^{20}$

No caso do Brasil, muitos trabalhos em demografia histórica tomam estas fontes como pedra fundamental, seja utilizando as técnicas de análise de domicílio, seja fazendo reconstituições de famílias. Para a Minas Gerais provincial, existem duas séries importantes de listas nominativas, uma para 1831-32 e outra para 1838-40. Estes conjuntos documentais foram trabalhados por pesquisadores do Centro de Desenvolvimento e Planejamento Regional da Faculdade de Economia da Universidade Federal de Minas Gerais (CEDEPLAR/FACE/ UFMG), codificando e digitando as informações neles contidos. ${ }^{21}$ Elas são

19 LASLETT, Peter. Introduction: the history of the family. In: LASLETT, Peter; WALL, Richard. (Eds.). Household and family in past time. 2. ed. Cambridge, 1974, p. 23-51.

20 HENRY, Louis. Técnicas de análise em demografia histórica. Lisboa: Gradiva, 1988.

21 Este trabalho esteve a cargo da equipe coordenada pelas pesquisadoras Clotilde Andrade Paiva e Maria do Carmo Salazar Martins, a quem agradeço pela cessão da base de dados. Alguns resultados preliminares obtidos com este material encontram-se em PAIVA, Clotilde Andrade. Minas Gerais no século XIX: aspectos demográficos de alguns núcleos populacionais. In: COSTA, I. D. N. da. (Org.). Brasil: história econômica e demográfica. São Paulo: IPE/USP, 1986. p. 173-187; e, PAIVA, Clotilde Andrade; ARNAUT, Luiz Duarte Haele. Fontes para o estudo de Minas oitocentista: listas nominativas. in. SEMINÁRIO SOBRE A ECONOMIA MINEIRA,5., Anais... Belo Horizonte: Cedeplar/Face/UFMG, 1990. p. 85-106. Para estudos mais recentes, ver: PAIVA, Clotilde Andrade. População e economia nas Minas Gerais do século XIX. São Paulo, 1996. Tese (Doutorado em História Social) - Universidade de São Paulo; RODARTE, Mário Marcos Sampaio. O caso das Minas que não se es gotaram: a pertinácia do antigo núcleo central minerador na expansão da malha urbana da Minas Gerais oitocentista. Belo Horizonte, 1999. Dissertação (Mestrado em Economia) - Cedeplar/Face/UFMG. ANDRADE, Cristiana Viegas de. Domicílios mineiros oitocentistas: uma aplicação do método Grade of Membership (GoM). Belo Horizonte, 2001. Dissertação (Mestrado em Demografia) Cedeplar / Face/ UFMG. 
resultado das tentativas de se realizarem recenseamentos gerais da província e foram organizadas sob a responsabilidade dos juízes de paz, em atendimento a solicitações do Governo Provincial. Objetivava-se com isto facilitar as deliberações da Administração Pública em áreas como tributos, divisão político-administrativa, recrutamento militar e outras.

As listas foram organizadas segundo os domicílios, com a relação nominal de todos os seus componentes. Para cada indivíduo, há informações quanto à cor, condição social (se livre, escravo ou liberto), idade e estado civil, podendo-se identificar o sexo pelo nome das pessoas. Além disso, traz a nacionalidade, para os não brasileiros, e as ocupações, principalmente para os chefes de domicílio. As listas de 1838/1840 informam-nos, ainda, sobre a alfabetização dos indivíduos (se sabe ou não ler ou escrever).

Esta riqueza de documentação censitária na década de 1830 reflete as preocupações do governo provincial mineiro com a organização político-administrativa, já enfatizadas anteriormente. Nas décadas seguintes, outras listas nominativas e mapas de população podem ser encontrados para alguns distritos e freguesias da Província de Minas Gerais. Entretanto, são esparsas e não apresentam a riqueza das séries aqui destacadas.

Nesta comunicação, uso as listas de 1831-32, por abrangerem um universo maior dentro da população mineira da época. Elas estão disponíveis para 234 dos 410 distritos de paz da província, cobrindo cerca de 57\% das localidades e contendo aproximadamente $55 \%$ da população mineira estimada para a primeira metade da década de 1830. Embora não possam ser tomadas como uma amostra no verdadeiro sentido do termo, permitem traçar um quadro bastante rico da Minas Gerais provincial, especialmente em função da máxima desagregação permitida por seus dados.

\section{Evidências}

Antes de partir para a exposição das evidências sobre o trabalho de crianças e jovens na Minas Gerais provincial, é necessário traçar um painel, ainda que rápido, da ocupação e posteriores transformações da região em estudo. O território que posteriormente formaria a província de Minas Gerais foi o 
palco das mais significativas mudanças da economia colonial a partir de finais do século XVIII graças às descobertas auríferas que os paulistas ali fizeram. As enormes reservas deste metal precioso atraíram um volume inédito de migrantes para uma região afastada do litoral. A grande concentração populacional e o seu rico mercado consumidor tornaram-na uma região articulada com vastas áreas da América portuguesa que se voltaram para seu abastecimento. De São Paulo, do Rio de Janeiro, do Rio Grande do Sul, da Bahia, de Pernambuco, passaram a se dirigir para as minas volumes cada vez maiores de mercadorias. $\mathrm{O}$ passar das décadas levou a própria região a desenvolver um setor interno voltado para o abastecimento de sua atividade central, que continuou a ser a extração aurífera até pelo menos a década de $1780 .^{22}$

Nas décadas finais do século XVIII, a capitania vivia uma conjuntura em que o declínio da mineração favorecia uma redefinição da economia regional, fazendo-a voltar-se para atividades abastecedoras, tanto primárias quanto de transformação. Tais atividades encontraram um excelente mercado na cidade do Rio de Janeiro, que a partir da primeira década do século XIX sofreria um crescimento vertiginoso devido à chegada da família real portuguesa. Por outro lado, a grande concentração populacional provocada pelas décadas seguidas de atividade mineratória garantiu a existência de um sólido mercado interno mesmo após o declínio das extrações auríferas. Este mercado interno passou a ser abastecido, sobretudo, por sua própria produção graças ao efeito protecionista provocado pela distância de portos e pelas dificuldades de acesso. Esta adaptação às transformações provocadas pelo declínio da mineração fez com

22 Sobre o século XVIII, abordando as transformações que iriam definir o papel da região após o declínio aurífero, ver: ZEMELLA, Mafalda P. O abastecimento da Capitania das Minas Gerais no século XVIII. 2. ed. São Paulo: Hucitec, Edusp, 1990 (1 ${ }^{\text {a }}$ ed.: 1951); MAXWELL, Kenneth. A devassa da devassa. 3. ed. Rio de Janeiro: Paz e Terra, 1985; GUIMARÃES, Carlos Magno, REIS, Liana Maria. Agricultura e escravidão em Minas Gerais (1700-1750). Revista do Departamento de História. Belo Horizonte. n. 2 , p. 7 36, Jun.1986; Id. Agricultura e caminhos de Minas (1700-1750). Revista do Departamento de História. Belo Horizonte. n. 4, p. 85-99, Jun.1987; CARRARA, Ângelo. Agricultura e pecuária na Capitania de Minas Gerais (1674-1807). Rio de Janeiro, 1997. Tese (Doutorado em História) - Universidade Federal do Rio de Janeiro; ALMEIDA, Carla Maria Carvalho de. Homens ricos, homens bons: produção e hierarquização social em Minas colonial, 1750-1822. Niterói, 2001. Tese (Doutorado em História); BRUGGER, Sílvia Maria Jardim. Minas patriarcal: família e sociedade (São João Del Rei - séculos XVIII e XIX). Niterói (RJ), 2002. (Tese de Doutorado em História) - Universidade Federal Fluminense; SILVA, Flávio Marcus da. Subsistência e poder: a política de abastecimento alimentar nas Minas setecentistas. Belo Horizonte, 2002. (Tese de Doutorado em História) - Universidade Federal de Minas Gerais. 
que Minas Gerais continuasse a ser a principal região escravista do Brasil até o final da instituição. ${ }^{23}$

Percorrendo o século XIX, existem três levantamentos populacionais que cobriram toda a província mineira e que permitem acompanhar o evolver de sua população: em 1818, em 1833-1835 e em $1872 .{ }^{24}$ Para o primeiro intervalo de tempo, houve um crescimento anual de $1,87 \%$, saltando para $2,84 \%$ entre os anos de 1833-1835 e 1872. Os escravos mantiveram-se respondendo por um terço do total de habitantes até pelo menos 1833-1835, declinando em 1872 para $18,2 \%$. Este declínio na participação total ocorreu mesmo com taxas de crescimento anual muito superiores às do Brasil em geral: $2 \%$ ao ano entre $1818 \mathrm{e}$ $1833-1835$ e $1,2 \%$ ao ano entre $1833-1835$ e 1872 . Acontece que, no mesmo período a população livre passou de um crescimento anual de 1,8\%, entre 1818 e 1833-1835, para 3,4\% até 1872. (Tabela 1). Estes índices são compatíveis com as conclusões das análises atuais sobre a província mineira, onde o declínio da mineração e a ausência de uma economia exportadora não significaram uma regressão econômica e, conseqüentemente, demográfica; ao contrário, Minas Gerais manteve a maior população, livre e cativa, do Brasil imperial e conheceu elevadas taxas de crescimento demográfico. Tal comportamento conviveu com razões de sexo, equilibradas entre os livres, embora com uma tendência ao predomínio masculino ao final do século: de 98 em 1818 para 103 em 1872. Quanto aos escravos, o amplo predomínio masculino declinou ao longo do período, passando de 148, em 1818, para 116, em 1872 (Tabela 2).

Conforme dito anteriormente, as listas nominativas de 1831-1832 estão disponíveis para 234 dos 410 distritos de paz da província, cobrindo cerca de $57 \%$ das localidades e contendo aproximadamente $55 \%$ da população mineira estimada para a primeira metade da década de 1830. Elas trazem 381.443 pesso-

23 Sobre as transformações na economia mineira desde a crise da mineração e através do século XIX, ver: LENHARO, Alcir. As tropas da moderação. São Paulo: Símbolo, 1979; MARTINS, Roberto B., MARTINS FILHO, Amilcar V. Slavery in a non-export economy: nineteenth-century Minas Gerais revisited. Hispanic American Historical Review. v. 63 n, 3 p. 537-68, Aug. 1983; LUNA, Francisco Vidal, CANO, Wilson. Economia escravista em Minas Gerais. Cadernos IFCH-UNICAMP, n. 10. Campinas, out. 1983; SLENES, Robert. Os múltiplos de porcos e diamantes. Cadernos IFCH-UNICAMP, n. 17. Campinas, jun. 1985; LIBBY, Douglas. Transformação e trabalho em uma economia escravista. São Paulo: Brasiliense, Brasília: CNPq, 1988; PAIVA, op. cit. GRAÇA FILHO, Afonso de Alencastro. A Princesa do Oeste e o mito da decadência de Minas Gerais: São João Del Rei (1831-1888). São Paulo: Annablume, São João Del Rei: UFSJ, 2002.

24 Os dados de 1818 foram extraídos de uma tabela impressa organizada por Luiz Maria da Silva Pinto trazendo como data o ano de 1821; entretanto, utiliza levantamentos que vão de 1812 a 1820 . Como a maior parte dos levantamentos é dos anos de 1818 e 1819, optei por utilizar o ano de 1818 como referência. Para os cálculos com os dados de 1833-35, usei como referência o ano de 1834. O governo provincial tentou organizar um levantamento na segunda metade da década de 1850, mas sua incompletude não permite a utilização sem que sejam feitos inúmeros ajustes e estimativas; optei por não usá-lo aqui. 
TABELA 1 - POPULAÇÃO SEGUNDO A CONDIÇÃO SOCIAL, PROVINCIA DE MINAS GERAIS, 1818-1872

\begin{tabular}{ccccccccc}
\hline \multirow{2}{*}{ Ano } & $\mathrm{N}$ & $\begin{array}{c}\text { Livres } \\
\%\end{array}$ & $\begin{array}{c}\text { Cresc. } \\
\text { Anual }\end{array}$ & $\mathrm{N}$ & $\begin{array}{c}\text { Escravos } \\
\%\end{array}$ & $\begin{array}{c}\text { Cresc. } \\
\text { Anual }\end{array}$ & $\mathrm{N}$ & $\begin{array}{c}\text { Cresc. } \\
\text { Anual }\end{array}$ \\
\hline 1818 & 343327 & 66,73 & & 171184 & 33,27 & & 514511 & \\
$1833-35$ & 458073 & 66,05 & 1,80 & 235476 & 33,95 & 1,99 & 693549 & 1,87 \\
1872 & 1669419 & 81,80 & 3,40 & 371362 & 18,20 & 1,20 & 2040781 & 2,84 \\
\hline
\end{tabular}

Obs.: O crescimento anual calculado até 1872 tomou como data inicial o ano de 1834.

TABELA 2 - POPULAÇÃO POR SEXO E CONDIÇÃO SOCIAL, PROVINCIA DE MINAS GERAIS, 1818-1872

\begin{tabular}{ccccccc}
\hline Ano & Homens & $\begin{array}{c}\text { Livres } \\
\text { Mulheres }\end{array}$ & $\begin{array}{c}\text { Razão } \\
\text { de Sexo }\end{array}$ & Homens & $\begin{array}{c}\text { Escravos } \\
\text { Mulheres }\end{array}$ & $\begin{array}{c}\text { Razão } \\
\text { de Sexo }\end{array}$ \\
\hline 1818 & 169973 & 173354 & 98 & 102237 & 68947 & 148 \\
$1833-35$ & 226280 & 231793 & 98 & 138231 & 97245 & 142 \\
1872 & 847824 & 821595 & 103 & 199537 & 171825 & 116 \\
\hline
\end{tabular}

Fonte: BOTELHO, 1998.

as, sendo 252.014 livres (66\% do total) e 129.429 cativos (34\% do total). Dentre os livres, existem 123.178 homens (49\% dos livres) e 128.613 mulheres (51\% dos livres), com a razão de sexos igual a 95. Os escravos se dividiam em 79.643 homens (61,5\% dos cativos) e 49.779 mulheres (38,5\% dos cativos), com a razão de sexos igual a $160 .{ }^{25}$

Observemos o perfil geral das crianças e jovens com menos de 21 anos, incluídas nestas observações. Elas respondiam por 53,1\% da população livre e por 45,6\% dos cativos. Entre os livres, havia um predomínio de homens nas faixas etárias inferiores, o qual transformava-se em predomínio das mulheres a partir dos 14 anos. Para os escravos, a situação invertia-se, e passava-se de uma ligeira predominância feminina até os 6 anos de idade para um predomínio cada vez mais masculino nas faixas etárias seguintes, até atingir um brutal desequilíbrio após os 21 anos (Tabela 3). Estas razões de sexo refletem os

25 A discrepância nas totalizações deve-se à existência de 223 livres e 7 escravos sem informação de sexo, desconsiderados na análise. Estes dados agregados foram retirados de ANDRADE, op. cit. p. 26-27. 
efeitos da migração diferencial entre os sexos. Para os homens livres, parece haver uma saída acentuada a partir dos 14 anos. Para os cativos, estamos simplesmente diante do impacto do tráfico escravista, extremamente seletivo do ponto de vista sexual e etário. A preferência por homens adultos levava a desequilíbrios enormes nas faixas etárias mais produtivas do ponto de vista da mão-de-obra. Cabe observar, contudo, como a faixa etária inicial, composta por aqueles com menos de 7 anos de idade, apresenta-se equilibrada, denotando a importância da reprodução natural na composição deste segmento da população.

TABELA 3 - PARTICIPAÇÃO DE CRIANÇAS E JOVENS NA POPULAÇÃO DE MINAS GERAIS, 1831- 1832.

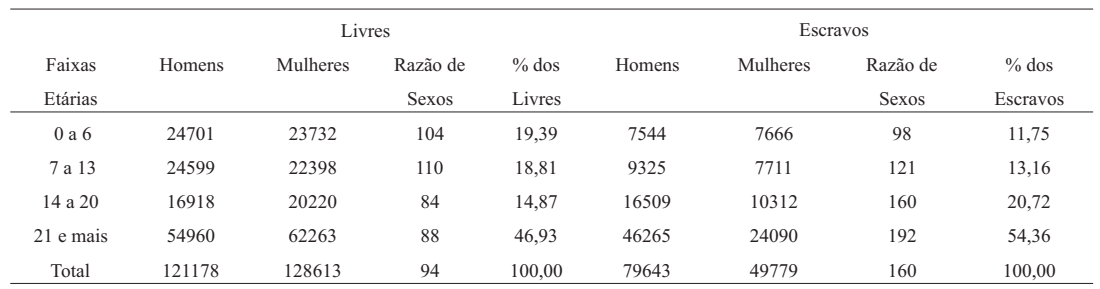

Fonte: Arquivo Público Mineiro. Listas Nominativas de Habitantes de 1831-1832.

Conforme assinalado anteriormente, a ocupação era uma das informações presentes nestas listas. Será através dela que tentarei me aproximar da questão do trabalho de crianças e jovens. Como apareciam as declarações sobre a ocupação destes segmentos da população? A principal dificuldade deve-se à omissão da informação. Todos aqueles que trabalham com as listas nominativas de habitantes de 1831-1832 apontam para seus problemas de cobertura neste quesito, o que dificulta o uso destes dados em todo o seu potencial. A maioria dos trabalhos concentra-se na ocupação declarada para os chefes de domicílios, supondo-se que a atividade desempenhada por eles influenciaria as atividades econômicas de todo o domicílio. ${ }^{26}$ Entretanto, para o que me preocupa neste momento, este dado é insuficiente. Interessa saber o que se declarava como ocupação (ou não) das crianças e jovens naquele momento, a qual deveria estar sendo influenciada pela atividade principal do domicílio, mas certamente apresentava certas especificidades.

Portanto, o primeiro passo é analisar a ausência da informação de ocupação nos grupos etários escolhidos. A Tabela 4 apresenta o perfil da omissão

26 Este é o procedimento utilizado por PAIVA, op. cit., e ANDRADE, op. cit. 
de ocupações na confecção das listas nominativas. A quase totalidade das crianças com 6 anos ou menos não tem sua ocupação declarada (mais de $98 \%$ para livres e escravos de ambos os sexos). Lembro que neste caso estou tratando da ausência completa de qualquer referência a este quesito, pois qualquer declaração (desocupado, não trabalha etc.) foi excluída deste índice. Para as crianças entre 7 e 13 anos, cai o percentual de omissão da informação, mas ainda é elevado, situando-se entre $80 \%$ e $85 \%$ entre livres e escravos de ambos os sexos. Apenas no segmento de 14 a 21 anos ocorre uma melhora significativa da qualidade da informação, com $46 \%$ dos homens e $51 \%$ das mulheres sem a declaração. No caso dos escravos, o índice é bem mais elevado, correspondendo a cerca de $65 \%$ dos homens e $64 \%$ das mulheres; neste caso, o segmento cativo como um todo apresenta uma baixa qualidade desta informação. ${ }^{27}$

TABELA 4 - CRIANÇAS E JOVENS SEM DECLARAÇÃO DE OCUPAÇÃO, MINAS GERAIS, 1831-1832.

\begin{tabular}{ccccccccc}
\hline & \multicolumn{3}{c}{ Livres } & \multicolumn{2}{c}{ Escravos } \\
Faixas & \multicolumn{2}{c}{ Homens } & \multicolumn{2}{c}{ Mulheres } & \multicolumn{2}{c}{ Homens } & \multicolumn{2}{c}{ Mulheres } \\
Etárias & $\mathrm{N}$ & $\%$ & $\mathrm{~N}$ & $\%$ & $\mathrm{~N}$ & $\%$ & $\mathrm{~N}$ & $\%$ \\
\hline 0 a 6 & 24245 & 98,15 & 23313 & 98,23 & 7436 & 98,57 & 7550 & 98,49 \\
7 a 13 & 20826 & 84,66 & 18383 & 82,07 & 7767 & 83,29 & 6218 & 80,64 \\
14 a 20 & 7831 & 46,29 & 10271 & 50,80 & 10747 & 65,10 & 6564 & 63,65 \\
Total & 52902 & 79,89 & 51967 & 78,32 & 25950 & 77,75 & 20332 & 79,15 \\
\% Pop. Total & & 43,66 & & 40,41 & & 32,58 & & 40,84 \\
\hline
\end{tabular}

Fonte: Arquivo Público Mineiro. Listas Nominativas de Habitantes de 1831-1832.

Por outro lado, a omissão da ocupação das crianças e jovens distribuise de maneira bastante uniforme entre as diversas regiões da província mineira (Mapa 1). ${ }^{28}$ Apenas para as regiões de Minas Novas (para os segmentos de 0 a 6 anos e de 7 a 13 anos), Vale Alto-Médio S.Francisco, Médio-Baixo R.das Velhas e Triângulo (para o segmento de 0 a 6 anos) há uma melhora nos dados sobre a ocupação das crianças (Tabelas 5 e 6). No caso dos jovens de 14 a 21

27 ANDRADE, op. cit., p. 34.

28 Adotou-se a regionalização construída por GODOY, Marcelo Magalhães. Intrépidos viajantes e a construção do espaço: uma proposta de regionalização para Minas Gerais do século XIX. Belo Horizonte: Cedeplar/Face/UFMG, 1996. (Texto para Discussão n. 109), baseada em extensa pesquisa a fontes primárias do próprio século XIX, como viajantes estrangeiros, documentação oficial e outras. Esta regionalização foi utilizada, com sucesso, em PAIVA, op. cit., RODARTE, op. cit., e ANDRADE, op. cit. 
anos, as regiões apresentam variações, mas apenas para o Sertão, Paracatu, Diamantina e Mineradora Central Leste há uma piora sensível dos dados. Pontualmente, algumas também se destacam pela má qualidade, como acontece com Minas Novas e Sudoeste para os homens livres, Minas Novas e Sudeste para as mulheres livres, Sudeste, Sul Central e Sudoeste para os homens escravos e Sudeste e Sudoeste para as mulheres escravas (Tabela 7). Portanto, antes de tudo reafirma-se a dificuldade em abordar o tema do trabalho infantil no passado, pois vigora um enorme silêncio sobre ele.

MAPA 1 - REGIÕES DA PROVÍNCIA DE MINAS GERAIS, 1831 - 1832.

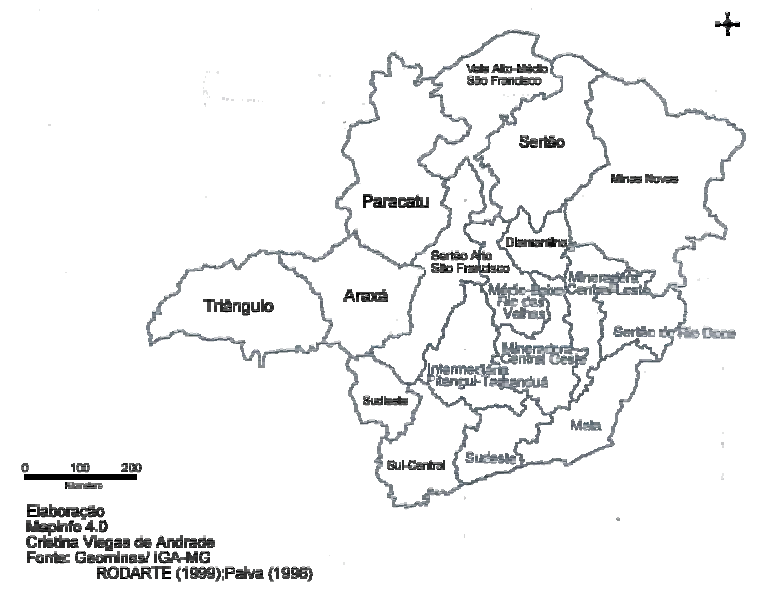

Em função da grande omissão de informações para as crianças entre 0 e 6 anos, vou ater-me à análise da ocupação declarada para os dois segmentos seguintes, que chamarei de crianças (7 a 13 anos) e jovens (14 a 21 anos). A grande variedade de ocupações declaradas nas listas nominativas (cerca de 800) levou à necessidade de agrupá-las, reduzindo-as a 9 grupos. Comecemos pelos homens livres. As crianças encontravam-se ocupadas sobretudo na Agropecuária, situação que se repetirá nos outros grupos masculinos em aná- 
TABELA 5- CRIANÇAS DE 0 A 6 ANOS SEM DECLARAÇÃO DE OCUPAÇÃO , POR REGIÕES , MINAS GERAIS , 1831-1832

\begin{tabular}{|c|c|c|c|c|c|c|c|c|c|c|c|c|}
\hline \multirow{3}{*}{ Regiões } & \multicolumn{4}{|c|}{ Livres } & \multicolumn{4}{|c|}{ Escravos } & \multicolumn{4}{|c|}{ Totais da faixa etária } \\
\hline & \multicolumn{2}{|c|}{ Homens } & \multicolumn{2}{|c|}{ Mulheres } & \multicolumn{2}{|c|}{ Homens } & \multicolumn{2}{|c|}{ Mulheres } & \multicolumn{2}{|c|}{ Livres } & \multicolumn{2}{|c|}{ Escravos } \\
\hline & $\mathrm{N}$ & $\%$ & $\mathrm{~N}$ & $\%$ & $\mathrm{~N}$ & $\%$ & $\mathrm{~N}$ & $\%$ & $\mathrm{H}$ & $\mathrm{M}$ & $\mathrm{H}$ & M \\
\hline Vale Alto-Médio S.Francisco & 58 & 96,67 & 44 & 84,62 & 13 & 100,00 & 9 & 100,00 & 60 & 52 & 13 & 9 \\
\hline Sertão & 868 & 99,88 & 718 & 99,86 & 120 & 100,00 & 136 & 100,00 & 869 & 719 & 120 & 136 \\
\hline Minas Novas & 340 & 51,99 & 339 & 52,31 & 56 & 52,83 & 55 & 48,67 & 654 & 648 & 106 & 113 \\
\hline Paracatu & 90 & 100,00 & 86 & 100,00 & 35 & 100,00 & 25 & 100,00 & 90 & 86 & 35 & 25 \\
\hline Sertão Alto S.Francisco & 353 & 99,72 & 384 & 99,74 & 93 & 100,00 & 102 & 100,00 & 354 & 385 & 93 & 102 \\
\hline Médio-Baixo R.das Velhas & 1303 & 99,47 & 1235 & 99,52 & 356 & 95,44 & 331 & 97,35 & 1310 & 1241 & 373 & 340 \\
\hline Sertão R.Doce & 31 & 100,00 & 34 & 100,00 & 0 & - & 1 & 100,00 & 31 & 34 & 0 & 1 \\
\hline Triângulo & 180 & 100,00 & 183 & 99,46 & 40 & 93,02 & 39 & 100,00 & 180 & 184 & 43 & 39 \\
\hline Araxá & 1193 & 97,55 & 1171 & 97,58 & 305 & 97,13 & 261 & 95,26 & 1223 & 1200 & 314 & 274 \\
\hline Inter. Pitangui-Tamanduá & 3559 & 99,94 & 3399 & 99,91 & 1296 & 99,46 & 1286 & 99,46 & 3561 & 3402 & 1303 & 1293 \\
\hline Diamantina & 605 & 98,06 & 537 & 97,11 & 64 & 98,46 & 63 & 100,00 & 617 & 553 & 65 & 63 \\
\hline Mineradora Central Leste & 1240 & 100,00 & 1091 & 99,82 & 395 & 100,00 & 339 & 100,00 & 1240 & 1093 & 395 & 339 \\
\hline Mineradora Central Oeste & 6028 & 99,18 & 5850 & 99,69 & 2005 & 99,50 & 2117 & 99,02 & 6078 & 5868 & 2015 & 2138 \\
\hline Mata & 1078 & 99,91 & 1051 & 99,62 & 364 & 98,64 & 398 & 99,50 & 1079 & 1055 & 369 & 400 \\
\hline Sudeste & 2048 & 99,61 & 2051 & 99,71 & 993 & 99,80 & 1028 & 99,90 & 2056 & 2057 & 995 & 1029 \\
\hline Sul Central & 3582 & 99,28 & 3477 & 99,60 & 966 & 99,59 & 1006 & 99,60 & 3608 & 3491 & 970 & 1010 \\
\hline Sudoeste & 1689 & 99,88 & 1663 & 99,94 & 335 & 100,00 & 354 & 99,72 & 1691 & 1664 & 335 & 355 \\
\hline PROVÍNCIA & 24245 & 98,15 & 23313 & 98,23 & 7436 & 98,57 & 7550 & 98,49 & 24701 & 23732 & 7544 & 7666 \\
\hline
\end{tabular}

obs.: O percentual refere-se à participação destas crianças no total de crianças de 0 a 6 anos de cada região. Fonte: Arquivo Público Mineiro. Listas Nominativas de Habitantes de 1831-1832.

TABELA 6- CRIANÇAS DE 7 A 13 ANOS SEM DECLARAÇÃO DE OCUPAÇÃO, POR REGIÕES, MINAS GERAIS, 1831-1832.

\begin{tabular}{|c|c|c|c|c|c|c|c|c|}
\hline \multirow{3}{*}{ Regiões } & \multicolumn{4}{|c|}{ Livres } & \multicolumn{4}{|c|}{ Escravos } \\
\hline & \multicolumn{2}{|c|}{ Homens } & \multicolumn{2}{|c|}{ Mulheres } & \multicolumn{2}{|c|}{ Homens } & \multicolumn{2}{|c|}{ Mulheres } \\
\hline & $\mathrm{N}$ & $\%$ & $\mathrm{~N}$ & $\%$ & $\mathrm{~N}$ & $\%$ & $\mathrm{~N}$ & $\%$ \\
\hline Vale Alto-Médio S.Francisco & 4 & 5,97 & 8 & 14,29 & 1 & 9,09 & 3 & 23,08 \\
\hline Sertão & 665 & 96,52 & 614 & 97,31 & 141 & 92,16 & 125 & 93,28 \\
\hline Minas Novas & 462 & 59,92 & 388 & 59,97 & 92 & 63,89 & 72 & 56,69 \\
\hline Paracatu & 91 & 100,00 & 80 & 100,00 & 26 & 100,00 & 21 & 100,00 \\
\hline Sertão Alto S.Francisco & 430 & 94,92 & 356 & 88,56 & 96 & 90,57 & 82 & 93,18 \\
\hline Médio-Baixo R.das Velhas & 926 & 71,84 & 783 & 70,86 & 322 & 71,40 & 272 & 69,39 \\
\hline Sertão R.Doce & 31 & 100,00 & 24 & 77,42 & 0 & - & 1 & 100,00 \\
\hline Triângulo & 118 & 75,64 & 86 & 66,67 & 20 & 52,63 & 34 & 66,67 \\
\hline Araxá & 954 & 82,67 & 844 & 82,42 & 284 & 78,45 & 239 & 81,57 \\
\hline Inter. Pitangui-Tamanduá & 2942 & 88,03 & 2658 & 84,68 & 1311 & 85,19 & 1065 & 81,36 \\
\hline Diamantina & 605 & 92,23 & 617 & 95,81 & 107 & 90,68 & 65 & 95,59 \\
\hline Mineradora Central Leste & 1121 & 98,68 & 1068 & 96,83 & 351 & 93,10 & 260 & 90,91 \\
\hline Mineradora Central Oeste & 5340 & 80,47 & 4549 & 76,06 & 2234 & 82,10 & 1732 & 78,19 \\
\hline Mata & 893 & 84,25 & 732 & 77,05 & 425 & 81,73 & 320 & 78,62 \\
\hline Sudeste & 1834 & 90,34 & 1630 & 90,01 & 1071 & 88,29 & 922 & 90,93 \\
\hline Sul Central & 2890 & 86,22 & 2536 & 83,12 & 947 & 81,64 & 722 & 76,56 \\
\hline Sudoeste & 1520 & 90,15 & 1410 & 87,36 & 339 & 87,82 & 283 & 81,09 \\
\hline \multirow[t]{2}{*}{ PROVÍNCIA } & 20826 & 84,66 & 18383 & 82,07 & 7767 & 83,29 & 6218 & 80,64 \\
\hline & 52902 & & 51967 & & 25950 & & 20332 & \\
\hline
\end{tabular}

\begin{tabular}{c|c|c|c|}
\multicolumn{4}{c}{ Totais da faixa etária } \\
Livres & \multicolumn{2}{c}{ Escravos } \\
$\mathrm{H}$ & $\mathrm{M}$ & $\mathrm{H}$ & $\mathrm{M}$ \\
67 & 56 & 11 & 13 \\
689 & 631 & 153 & 134 \\
771 & 647 & 144 & 127 \\
91 & 80 & 26 & 21 \\
453 & 402 & 106 & 88 \\
1289 & 1105 & 451 & 392 \\
31 & 31 & 0 & 1 \\
156 & 129 & 38 & 51 \\
1154 & 1024 & 362 & 293 \\
3342 & 3139 & 1539 & 1309 \\
656 & 644 & 118 & 68 \\
1136 & 1103 & 377 & 286 \\
6636 & 5981 & 2721 & 2215 \\
1060 & 950 & 520 & 407 \\
2030 & 1811 & 1213 & 1014 \\
3352 & 3051 & 1160 & 943 \\
1686 & 1614 & 386 & 349 \\
24599 & 22398 & 9325 & 7711
\end{tabular}

Fonte: Arquivo Público Mineiro. Listas Nominativas de Habitantes de 1831-1832. 
TABELA 7- JOVENS DE 14 A 20 ANOS SEM DECLARAÇÃO DE OCUPAÇÃO, POR REGIÕES, MINAS GERAIS, 1831-1832.

\begin{tabular}{|c|c|c|c|c|c|c|c|c|}
\hline \multirow{3}{*}{ Regiões } & \multicolumn{4}{|c|}{ Livres } & \multicolumn{4}{|c|}{ Escravos } \\
\hline & \multicolumn{2}{|c|}{ Homens } & \multicolumn{2}{|c|}{ Mulheres } & \multicolumn{2}{|c|}{ Homens } & \multicolumn{2}{|c|}{ Mulheres } \\
\hline & $\mathrm{N}$ & $\%$ & $\mathrm{~N}$ & $\%$ & $\mathrm{~N}$ & $\%$ & $\mathrm{~N}$ & $\%$ \\
\hline Vale Alto-Médio S.Francisco & 0 & 0,00 & 0 & 0,00 & 0 & 0,00 & 0 & 0,00 \\
\hline Sertão & 387 & 74,14 & 480 & 84,81 & 144 & 77,42 & 95 & 74,22 \\
\hline Minas Novas & 312 & 60,58 & 393 & 63,08 & 111 & 66,07 & 105 & 62,13 \\
\hline Paracatu & 64 & 96,97 & 97 & 98,98 & 30 & 100,00 & 21 & 100,00 \\
\hline Sertão Alto S.Francisco & 117 & 37,74 & 197 & 56,61 & 94 & 58,02 & 68 & 61,26 \\
\hline Médio-Baixo R.das Velhas & 281 & 32,00 & 307 & 27,02 & 217 & 40,71 & 178 & 41,01 \\
\hline Sertão R.Doce & 2 & 18,18 & 0 & 0,00 & 2 & - & 1 & 50,00 \\
\hline Triângulo & 8 & 10,67 & 10 & 8,93 & 1 & 1,09 & 0 & 0,00 \\
\hline Araxá & 299 & 39,60 & 436 & 53,37 & 391 & 66,05 & 264 & 69,29 \\
\hline Inter. Pitangui-Tamanduá & 990 & 44,55 & 1209 & 43,02 & 1495 & 58,84 & 1012 & 59,60 \\
\hline Diamantina & 199 & 36,51 & 517 & 89,14 & 275 & 97,52 & 126 & 96,92 \\
\hline Mineradora Central Leste & 664 & 80,68 & 783 & 80,80 & 596 & 73,58 & 333 & 80,63 \\
\hline Mineradora Central Oeste & 1625 & 33,66 & 2123 & 36,86 & 2967 & 58,90 & 1610 & 53,24 \\
\hline Mata & 318 & 45,49 & 462 & 54,23 & 686 & 67,85 & 345 & 65,84 \\
\hline Sudeste & 726 & 52,80 & 1015 & 68,12 & 1677 & 76,51 & 1171 & 84,24 \\
\hline Sul Central & 1161 & 55,31 & 1445 & 54,06 & 1508 & 72,26 & 870 & 64,59 \\
\hline Sudoeste & 678 & 59,42 & 797 & 60,84 & 553 & 71,73 & 365 & 75,41 \\
\hline \multirow[t]{2}{*}{ PROVÍNCIA } & 7831 & 46,29 & 10271 & 50,80 & 10747 & 65,10 & 6564 & 63,65 \\
\hline & 52902 & & 51967 & & 25950 & & 20332 & \\
\hline
\end{tabular}

\begin{tabular}{c|c|c|c|}
\multicolumn{4}{c}{ Totais da faixa etária } \\
Livres & Escravos \\
$\mathrm{H}$ & $\mathrm{M}$ & $\mathrm{H}$ & $\mathrm{M}$ \\
55 & 56 & 13 & 5 \\
$\mathbf{5 2 2}$ & $\mathbf{5 6 6}$ & $\mathbf{1 8 6}$ & $\mathbf{1 2 8}$ \\
515 & 623 & 168 & 169 \\
$\mathbf{6 6}$ & $\mathbf{9 8}$ & $\mathbf{3 0}$ & $\mathbf{2 1}$ \\
310 & 348 & 162 & 111 \\
878 & 1136 & 533 & 434 \\
11 & 21 & 2 & 2 \\
75 & 112 & 92 & 48 \\
755 & 817 & 592 & 381 \\
2222 & 2810 & 2541 & 1698 \\
$\mathbf{5 4 5}$ & $\mathbf{5 8 0}$ & $\mathbf{2 8 2}$ & $\mathbf{1 3 0}$ \\
$\mathbf{8 2 3}$ & $\mathbf{9 6 9}$ & $\mathbf{8 1 0}$ & $\mathbf{4 1 3}$ \\
4827 & 5759 & 5037 & 3024 \\
699 & 852 & 1011 & 524 \\
1375 & 1490 & 2192 & 1390 \\
2099 & 2673 & 2087 & 1347 \\
1141 & 1310 & 771 & 484 \\
16918 & 20220 & 16509 & 10312 \\
& & &
\end{tabular}

Fonte: Arquivo Público Mineiro. Listas Nominativas de Habitantes de 1831-1832.

lise. ${ }^{29}$ Em seguida, vinham as Outras Atividades, que agregavam atividades pouco significativas quando tomadas isoladamente, mas que, do ponto de vista das crianças, eram importantes; é o caso, sobretudo, dos estudantes e aprendizes sem outras referências. Também as Atividades Manuais e Mecânicas eram importantes, certamente agregando aprendizes de ferreiros, de alfaiates, de carpinteiros e outros. Neste grupo etário pode-se destacar a enorme presença de crianças da região de Diamantina ocupadas com a Mineração (45\% do total de homens livres com declaração ocupada nesta faixa etária). Também nesta região o Comércio era importante empregador de crianças, além de encontrarmos diversas outras ocupadas em mais de uma atividade (Associações de Ocupações). Também é importante assinalar o enorme peso das crianças Desocupadas em Minas Novas, demonstrando o que disse anteriormente acerca da qualidade da informação. Neste caso, fica evidente que uma boa qualidade da informação deveria contemplar um significativo conjunto de crianças declaradas como sem ocupação (Tabela 8).

29 Cabe observar que o predomínio das atividades agropecuárias entre os homens estendia-se à população como um todo; ver ANDRADE, op. cit., p. 34-35. 
Os homens jovens livres também estavam principalmente na Agropecuária, mas ocupavam-se significativamente mais nas Atividades Manuais e Mecânicas, no Comércio e em Outras Atividades. As Atividades Manuais e Mecânicas tornamse ainda mais importantes nas regiões com uma vida econômica mais ativa e com uma rede urbana mais estruturada, como no centro da província e/ou antigos núcleos mineradores (Minas Novas, Médio-Baixo Rio das Velhas, Intermediária de PitanguiTamanduá, Diamantina e Mineradora Central Oeste) e no sul (Sudeste e Sul Central). Novamente Diamantina destaca-se com o emprego de jovens na Mineração, bem como a região de Minas Novas. A categoria de Desocupados reduz-se mesmo naquelas regiões com bom índice de declaração da ocupação, o que pode denotar o pressuposto de que aqueles com mais de 14 anos devem estar ocupados, exceto em situações excepcionais (Tabela 9).

As crianças do sexo feminino encontravam-se envolvidas predominantemente com as Atividades Manuais e Mecânicas. Neste caso, tratava-se das fiandeiras, tecedeiras, costureiras, rendeiras e suas aprendizes. ${ }^{30} \mathrm{~A}$ Agropecuária revestia-se de importância entre as meninas apenas na região de Diamantina e no Sertão, seguidas mais de longe pela Sudoeste, Mineradora Central Leste, Sudeste, Triângulo e Vale do Alto-Médio São Francisco. O Serviço Doméstico, tradicionalmente associado à condição feminina, aparece com algum peso apenas no Médio-Baixo Rio das Velhas e na região de Araxá. As Outras Atividades são importantes na Sul Central e Sudeste e a Mineração aparece em Diamantina. Deve-se chamar a atenção, novamente, para a forte presença de informação sobre Desocupados em Minas Novas, reflexo da maior cobertura de seus dados (Tabela 10).

Entre as jovens livres, de 14 a 20 anos, mantém-se o predomínio das Atividades Manuais e Mecânicas, com o Serviço Doméstico aparecendo nas regiões do Médio-Baixo Rio das Velhas e de Minas Novas e as Outras Atividades diminuindo sua incidência (aparecem em termos significativos apenas em Minas Novas e Araxá). A Agropecuária mantém-se como atividade de menor importância para as mulheres, destacando-se apenas nas regiões de Paracatu (um possível problema com os dados, pois representa 100\% das atividades das jovens), Mineradora Central Leste e Diamantina. Também no Vale do AltoMédio São Francisco e no Sertão a Agropecuária é importante, porém em grau bastante inferior. A Mineração continua a ser importante em Diamantina. Devese chamar a atenção para a queda no percentual de Desocupadas, reforçando

30 Da mesma forma que entre os homens, também as mulheres da população em geral se ocupavam do mesmo conjunto de atividades; ver ANDRADE, op. cit., p. 34-35. 


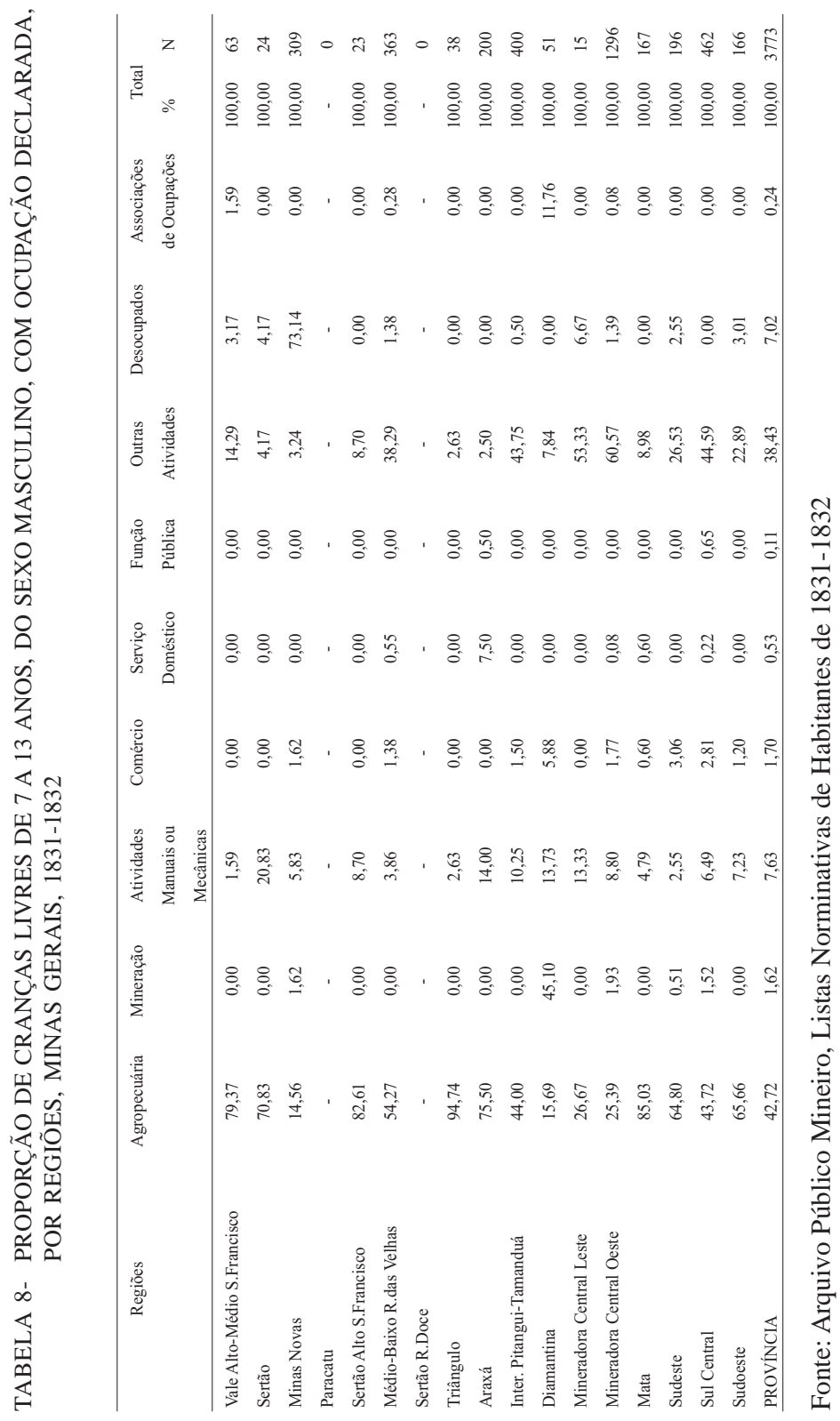




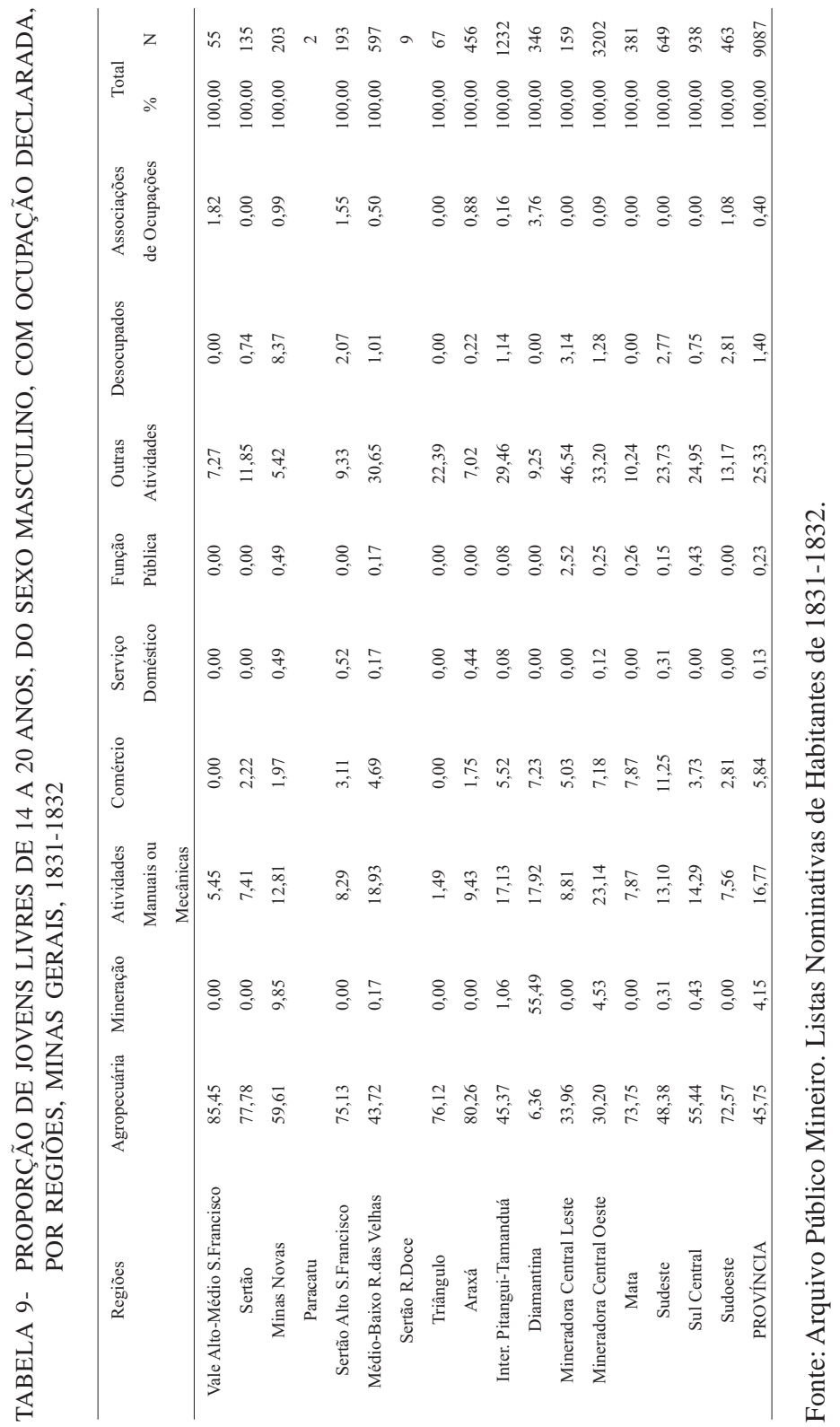




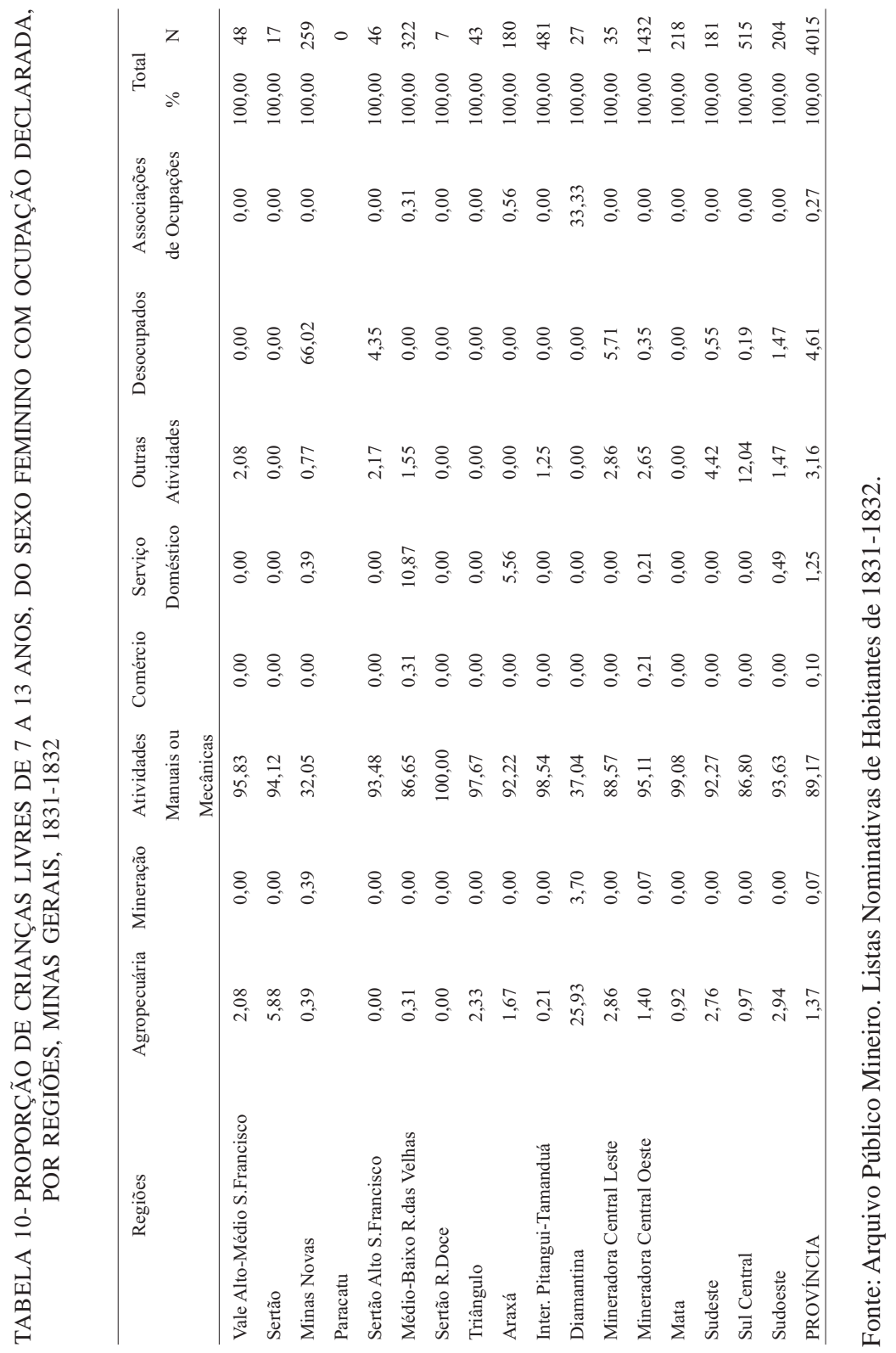


nossa interpretação acerca da universalização das ocupações após os 14 anos de idade (Tabela 11).

Passemos para o mundo dos cativos. As crianças desta condição ocupavam-se predominantemente da Agropecuária, Atividades Manuais e Mecânicas e Serviço Doméstico. Chama a atenção a importância da Mineração em três regiões: Mineradora Central Leste, Mineradora Central Oeste e Sul Central. Ao mesmo tempo, nota-se a ausência de cativos envolvidos com a atividade mineradora naquelas regiões que tinham livres ocupados com elas (Diamantina e Minas Novas). Pode-se aventar a hipótese de que a mineração, na porção setentrional da província, tornara-se uma atividade de baixo retorno econômico, desempenhada sobretudo por livres pobres através da chamada faiscação. Enquanto isso, na região central e no sul da província a atividade continuava a ser economicamente viável, permitindo a manutenção de escravos voltados para sua exploração. Outro destaque é a visível diminuição dos escravinhos considerados Desocupados. Neste caso, era difícil admitir um escravinho desocupado, já que certamente eram designados para pequenos trabalhos domésticos ou outras tarefas; daí sua maior presença nesta última categoria ou em Outras Atividades (Tabela 12).

A observação dos jovens escravos reforça as afirmações anteriores. Eles se dividem entre a Agropecuária, as Atividades Manuais e Mecânicas, o Serviço Doméstico e as Outras Atividades. Cabe destacar, todavia, a queda da participação do Serviço Doméstico como atividade dos jovens escravos. Também a Mineração apresenta o mesmo perfil detectado entre as crianças (presença destacada nas regiões Mineradora Central Leste, Mineradora Central Oeste e Sul Central; ausência nas demais), reforçando a hipótese anterior acerca do caráter assumido pela atividade no século XIX (Tabela 13).

As meninas escravas, como as livres, estavam ocupadas com as Atividades Manuais e Mecânicas (eram fiandeiras, tecedeiras, costureiras etc.) e, em menor grau, no Serviço Doméstico. A Agropecuária revestia-se de importância para as meninas cativas da região de Diamantina e da Mineradora Central Leste, bem como no Médio Baixo Rio das Velhas, no Sertão e no Alto-Médio São Francisco. É notória a maior participação do Serviço Doméstico, assim como observado entre os escravinhos. Aliado à menor incidência de Desocupados, isto mostra que o trabalho era parte do mundo dos cativos desde bastante cedo (Tabela 14).

As jovens escravas também se encontravam, sobretudo, nas Atividades Manuais e Mecânicas e, em menor grau, no Serviço Doméstico; neste último caso, deve-se destacar o grande aumento da sua maior participação. A Agropecuária é importante também na Mineradora Central Leste, Diamantina, Sertão e Médio Baixo Rio das Velhas (Tabela 15). 





BOTELHO, T. R. O trabalho de crianças e jovens no Brasil Imperial...

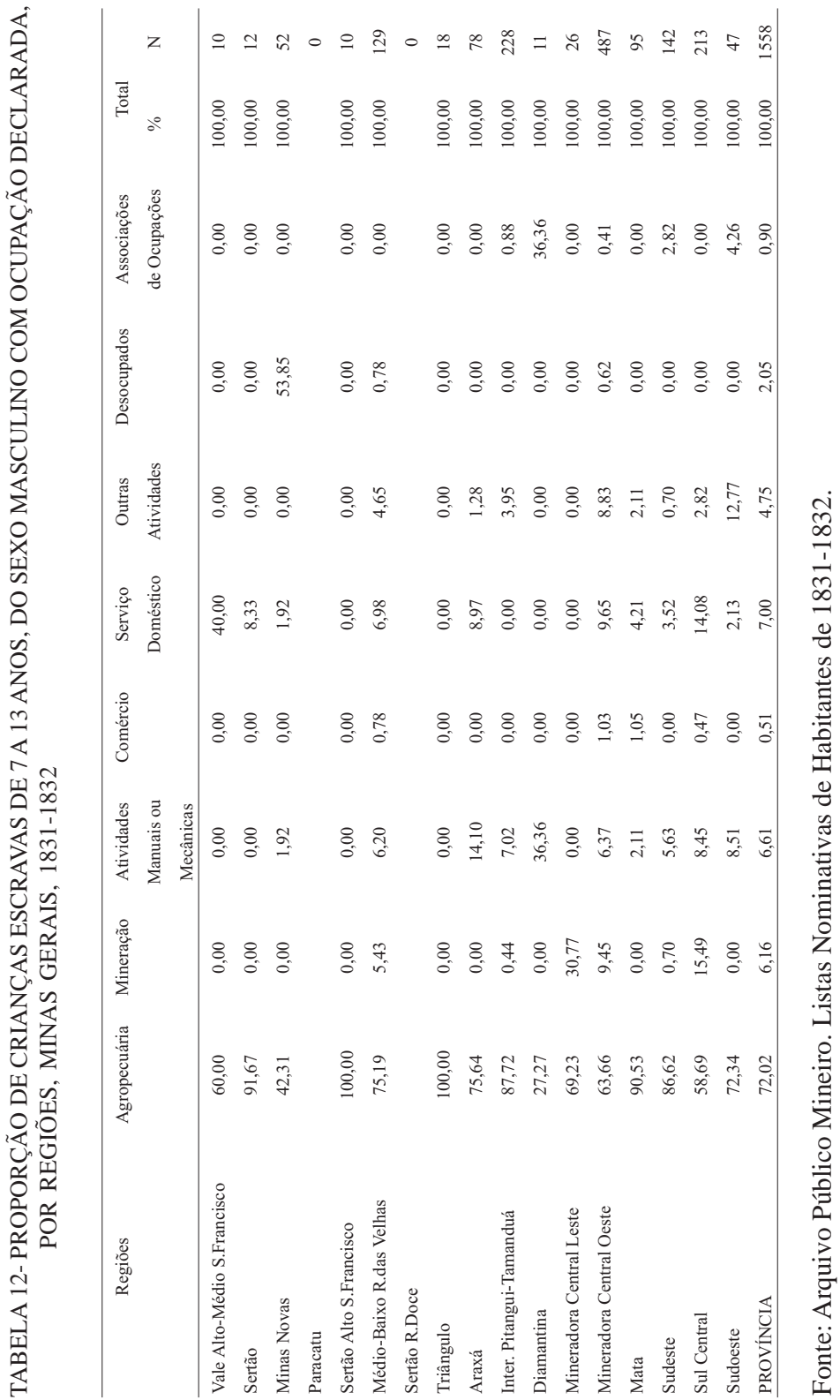




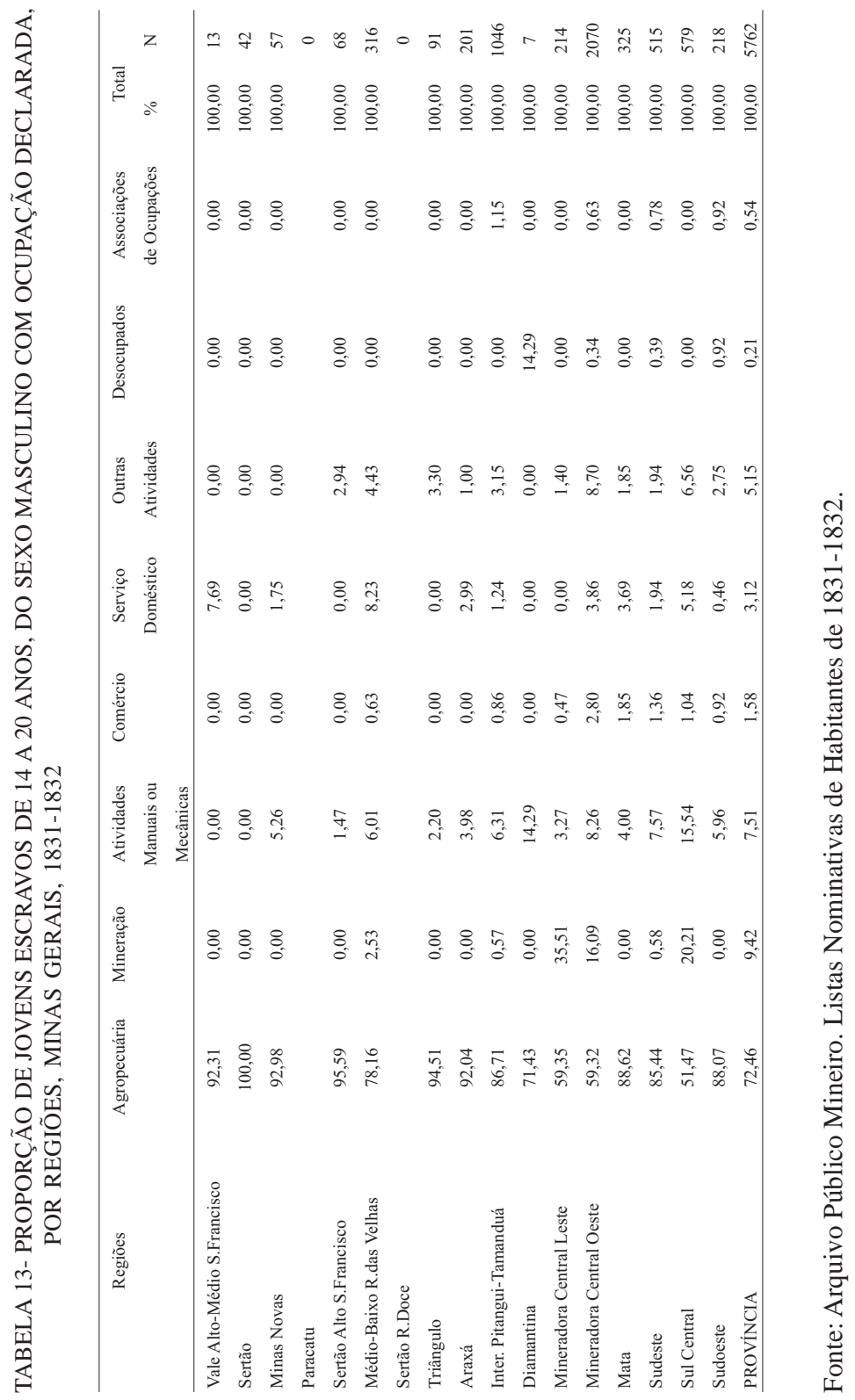


BOTELHO, T. R. O trabalho de crianças e jovens no Brasil Imperial...

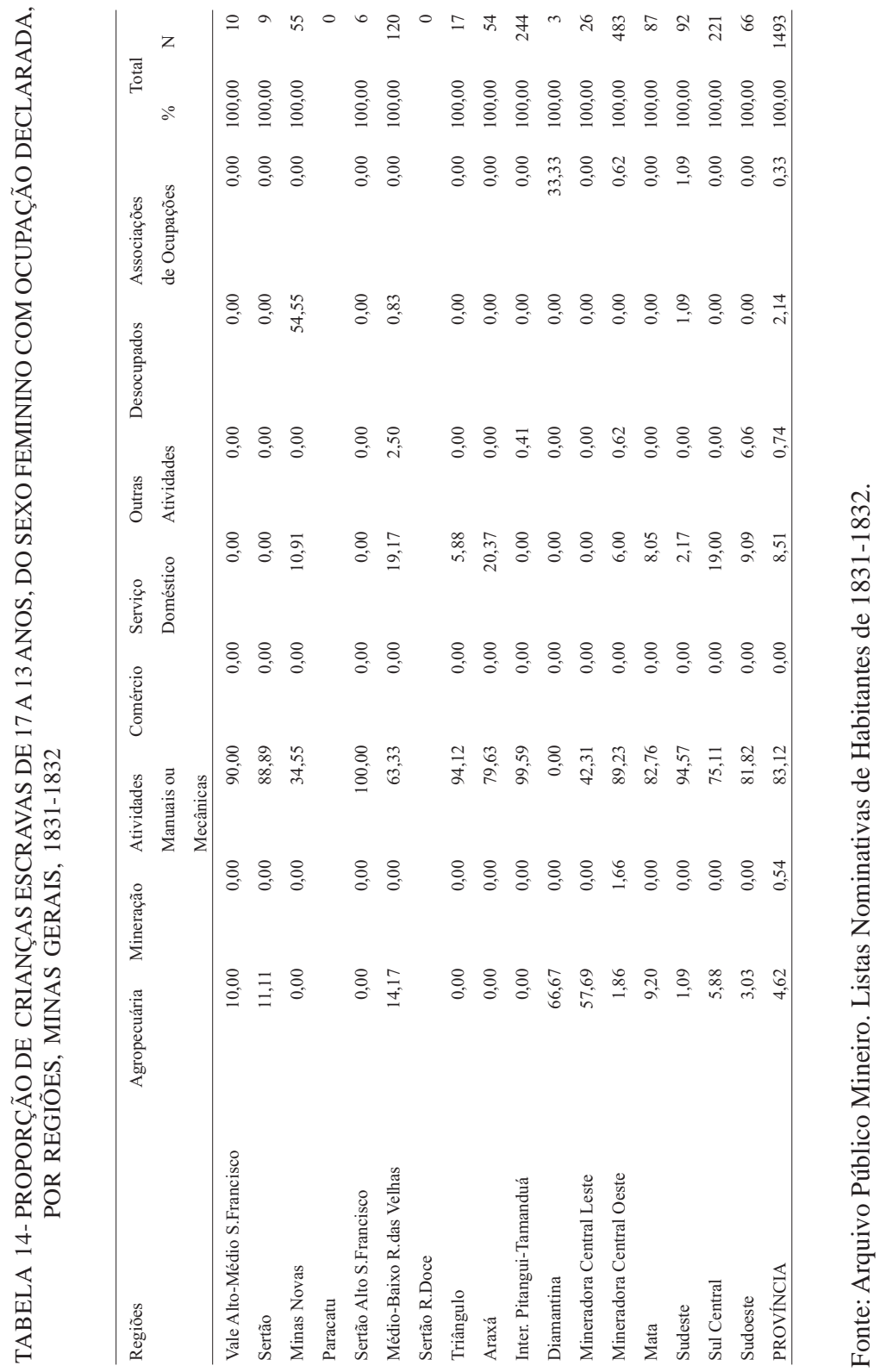




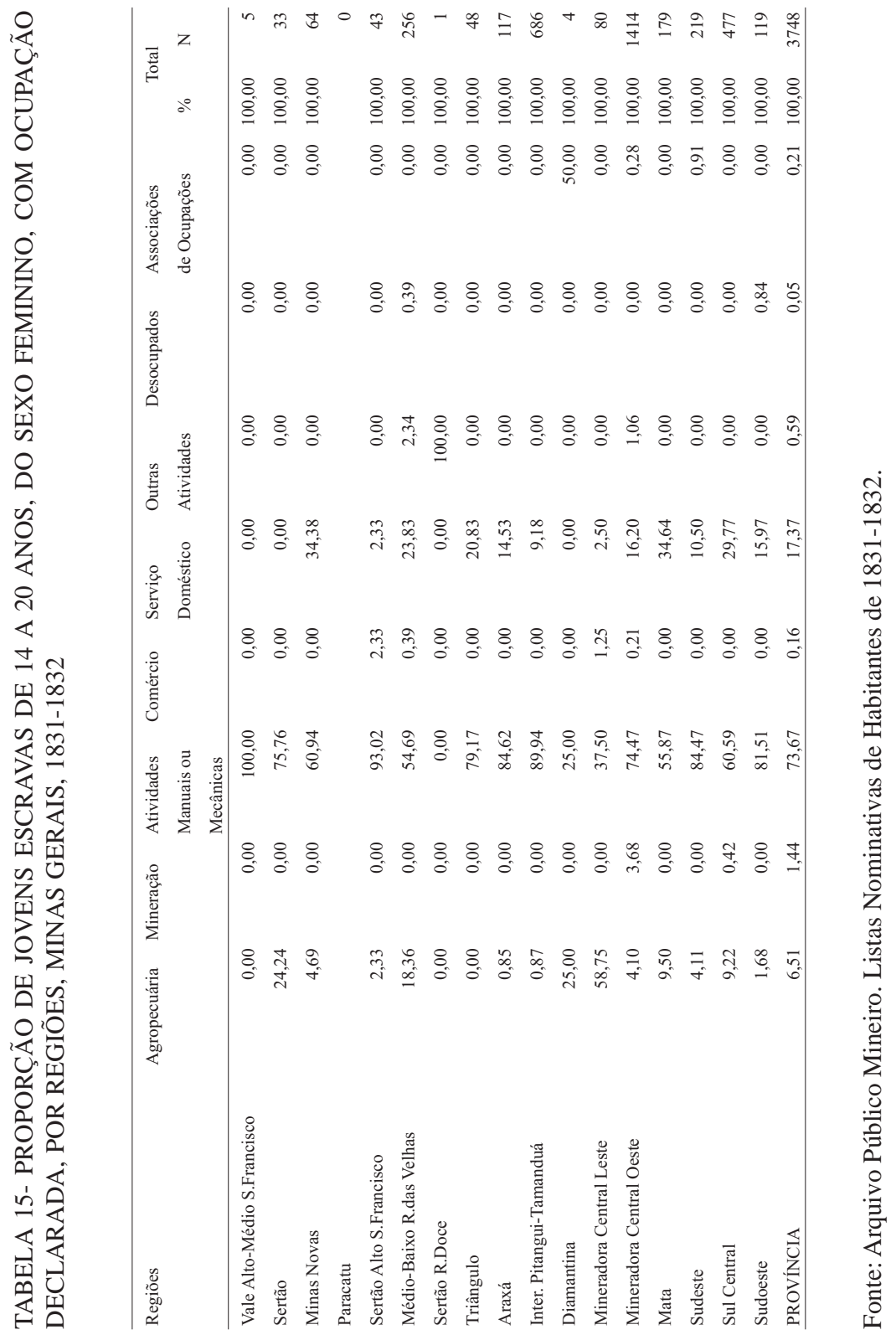




\section{Conclusões}

Apesar da precariedade dos dados, é possível destacar alguns aspectos que parecem caracterizar o mundo das crianças e jovens do século XIX mineiro e, provavelmente, brasileiro. Primeiramente, parece que os grupos etários aqui propostos correspondem a momentos de transformações reais no trabalho de crianças e jovens da época. Podemos admitir que a quase total ausência de informações para aqueles com 6 ou menos anos de idade reflete a sua exclusão do mundo do trabalho. A partir dos 7 anos, pois, estava-se pronto para trabalhar, ainda que através de uma inserção lateral. Aos 14 anos, por sua vez, estamos diante de um trabalhador pleno.

A segunda observação importante diz respeito ao fato do perfil das ocupações das crianças e jovens acompanhar aquele dos adultos. Os homens voltavam-se para a Agropecuária e, em segundo lugar, para as Atividades Manuais e Mecânicas. As mulheres dedicavam-se às Atividades Manuais e Mecânicas e, em grau extremamente inferior, à Agropecuária. Por outro lado, isto reflete outro aspecto relevante: o padrão do trabalho infantil no que diz respeito ao tipo de ocupação mostrou-se sensível ao perfil econômico das diversas regiões de Minas Gerais. Isto permite chamar a atenção para a necessidade de uma regionalização afinada com a realidade da época para poder perceber estas dinâmicas diferenciadas e assim traçar um perfil mais acurado da economia e da sociedade com a qual se esteja trabalhando. Penso que este é o desafio para quem deseja trabalhar com outros espaços.

Das duas observações anteriores decorre uma terceira: a de que as diferenciações observadas nos padrões de ocupação de crianças e jovens eram determinadas muito mais pelo sexo do que pela condição social. Em outras palavras, o perfil das mulheres livres aproximava-se mais do perfil das mulheres escravas que dos homens livres, e assim sucessivamente. Isto decorre, certamente, do fato de estarmos lidando com uma sociedade pré-industrial, onde, para o conjunto da população, uma divisão sexual do trabalho mostra-se mais importante que outras clivagens possíveis.

Apesar desta constatação, deve-se destacar, como quarta e última observação, que alguns aspectos permitem diferenciar livres e escravos, unificando-os independentemente do sexo. Apesar dos problemas de omissão de informações, creio ser possível afirmar que os escravinhos e as escravinhas eram chamados muito mais precocemente a integrar-se ao mundo do trabalho 
que os livres. Ainda que de modo imperfeito e gradual, esta inserção era efetiva, transparecendo por detrás das atividades domésticas e dos diversos períodos de aprendizagem das ocupações e, em alguns casos, dos ofícios especializados. Esta constatação pode parecer óbvia, mas é necessária para que não se perca a noção deste fosso crucial na vida dos brasileiros e que começava a ser cavado do ponto de vista prático a partir do mundo do trabalho.

\section{Referências}

ALMEIDA, Carla Maria Carvalho de. Homens ricos, homens bons: produção e hierarquização social em Minas colonial, 1750-1822. Niterói (RJ): UFF, 2001 (Tese de Doutorado - História).

ALVIM, Rosilene. Trabalho infantil: diversidade e exploração. IV Encontro Nacional de Estudos do Trabalho, 4., 1997, Anais... Rio de Janeiro: ABET, 1997. p. 299-318.

ANDRADE, Cristiana Viegas de. Domicílios mineiros oitocentistas: uma aplicação do método Grade of Membership (GoM). Belo Horizonte (MG): CEDEPLAR/FACE/ UFMG, 2001. (Dissertação de Mestrado - Demografia).

ARIÉS, Philippe. História social da criança e da família. Rio de Janeiro: Guanabara, 1981.

BOTELHO, Tarcísio R. População e nação no Brasil do século XIX. São Paulo:USP, 1998. (Tese de Doutorado - História Social).

BRUGGER, Sílvia Maria Jardim. Minas patriarcal: família e sociedade (São João Del Rei - séculos XVIII e XIX). Niterói (RJ): UFF, 2002. (Tese de Doutorado - História).

CARRARA, Ângelo. Agricultura e pecuária na Capitania de Minas Gerais (16741807). Rio de Janeiro (RJ): UFRJ, 1997. (Tese de Doutorado - História).

CASEY, James. A história da família. São Paulo: Ática, 1992.

GEBARA, Ademir. O mercado de trabalho livre no Brasil. São Paulo: Brasiliense, 1986.

GODOY, Marcelo Magalhães. Intrépidos viajantes e a construção do espaço: uma proposta de regionalização para Minas Gerais do século XIX. Belo Horizonte: CEDEPLAR/FACE/UFMG, 1996. (Texto para Discussão n. 109)

GRAÇA FILHO, Afonso de Alencastro. A Princesa do Oeste e o mito da decadência de Minas Gerais: São João Del Rei (1831-1888). São Paulo: Annablume, São João Del Rei (MG): UFSJ, 2002. 
GUIMARÃES, Carlos Magno, REIS, Liana Maria. Agricultura e caminhos de Minas (1700-1750). Revista do Departamento de História, Belo Horizonte, n. 4, p. 85-99, jun. 1987.

GUIMARÃES, Carlos Magno, REIS, Liana Maria. Agricultura e escravidão em Minas Gerais (1700-1750). Revista do Departamento de História, Belo Horizonte, n. 2, p. 736, jun. 1986.

GUTIÉRREZ, Horácio; LEWKOWICZ, Ida. Trabalho infantil em Minas Gerais na primeira metade do século XIX. Locus: Revista de História, v. 5, n. 2, p. 9-21, 1999.

HENRY, L.. Técnicas de análise em demografia histórica. Lisboa: Gradiva, 1988.

LAMOUNIER, Maria Lúcia. Da escravidão ao trabalho livre: a lei de locação de serviços de 1879. Campinas: Papirus, 1988.

LASLETT, P. Introduction: the history of the family. In: LASLETT, P., WALL, R. (Eds.). Household and family in past time. 2. ed. Cambridge: 1974.

LENHARO, Alcir. As tropas da moderação. São Paulo: Símbolo, 1979.

LIBBY, Douglas. Transformação e trabalho em uma economia escravista. São Paulo: Brasiliense, Brasília: CNPq, 1988.

LUNA, Francisco Vidal, CANO, Wilson. Economia escravista em Minas Gerais. Cadernos IFCH-UNICAMP, Campinas, n. 10, out. 1983.

MARCÍlIO, M. L.. A população do Brasil em perspectiva histórica. In: COSTA, I. D. N. da. (Org.). Brasil: história econômica e demográfica. São Paulo: IPE/USP, 1986. p. 11-27.

MARTINS, Roberto B., MARTINS FILHO, Amilcar V. Slavery in a non-export economy: nineteenth-century Minas Gerais revisited. Hispanic American Historical Review, v. 63, n. 3, p. 537-68, August, 1983.

MAXWELL, Kenneth. A devassa da devassa. 3 ed. Rio de Janeiro: Paz e Terra, 1985.

PAIVA, C. A., ARNAUT, L. D. H.. Fontes para o estudo de Minas oitocentista: listas nominativas. V Seminário sobre a Economia Mineira, Anais... Belo Horizonte: CEDEPLAR/FACE/UFMG, 1990. p. 85-106.

PAIVA, C. A., CARVAlHO, J. A. M. DE, LEITE, V. da M.. Demografia. In: Instituto Brasileiro de Geografia e Estatística - IBGE. Estatísticas históricas do Brasil: séries econômicas, demográficas e sociais de 1550 a 1988. Rio de Janeiro: IBGE, 1990.

PAIVA, C. A. Minas Gerais no século XIX: aspectos demográficos de alguns núcleos populacionais. In: COSTA, I. D. N. da (Org.). Brasil: história econômica e demográfica. São Paulo: IPE/USP, 1986. p. 173-187.

PAIVA, Clotilde Andrade. População e economia nas Minas Gerais do século XIX. São Paulo (SP): USP, 1996. (Tese de Doutorado - História Social) 
PIRES, Júlio Manuel. O trabalho infantil na legislação brasileira. IV Encontro Nacional de Estudos do Trabalho, Anais... Rio de Janeiro: ABET, 1997. p. 241-251.

RODARTE, Mário Marcos Sampaio. O caso das Minas que não se esgotaram: a pertinácia do antigo núcleo central minerador na expansão da malha urbana da Minas Gerais oitocentista. Belo Horizonte (MG): CEDEPLAR/FACE/UFMG, 1999. (Dissertação de Mestrado - Economia).

SILVA, Flávio Marcus da. Subsistência e poder: a política de abastecimento alimentar nas Minas setecentistas. Belo Horizonte (MG): UFMG, 2002 (Tese de Doutorado História).

SLENES, Robert. Os múltiplos de porcos e diamantes. Cadernos IFCH-UNICAMP,. Campinas, n. 17, jun. 1985.

VEIGA, João Paulo Cândia. A questão do trabalho infantil. São Paulo: ABET, 1998.

VENÂNCIO, Renato Pinto. Famílias abandonadas: assistência à criança de camadas populares no Rio de Janeiro e em Salvador, séculos XVIII e XIX. Campinas: Papirus, 1999.

ZEMELLA, Mafalda P. O abastecimento da Capitania das Minas Gerais no século XVIII. 2 ed. São Paulo: Hucitec, Edusp, 1990 (1. ed. 1951). 